\title{
NEW PATHWAYS TO SOCIAL CHANGE - CREATING IMPACT THROUGH SOCIAL INNOVATION RESEARCH
}

\author{
JÜRGEN HOWALDT \\ D0I: 10.22163/fteval.2019.365
}

The social sciences and humanities are deeply involved in the processes that use scientific and scholarly approaches to bring about a better society, difficult as it may be to define it.

(König et al. 2018)

\section{ABSTRACT}

$\mathrm{T}$ he paper emphasises the crucial role of social innovation in successfully addressing social, economic, political and environmental challenges of the 21 st century. In this context, the global mapping of the international research project SI-DRIVE reveals the capacities of social innovations to modify or even re-direct social change and to empower people -i.e. to address a wide variety of stakeholder groups, as well as the broader public, in order to improve social cohesion and to allow for smart, sustainable and inclusive growth. Like technological innovations, successful social innovations are based on numerous presuppositions and require appropriate infrastructures and resources. This includes a new role of public policy and government for creating suitable framework and support structures, the integration of the economy and civil society as well as supporting measures by science and universities (e.g. education for social innovation performance, know-how transfer).

This also raises the question of the role of universities in general and of social sciences in particular in social innovation processes. It will be a major challenge for the development of social innovation to ensure a much higher involvement of research and education facilities. In these processes social sciences will be challenged to redefine their functions with regard to innovation. In the past, innovation research in the context of social sciences has contributed to explain the social dimensions, the complexity and paradoxes of innovation processes. Henceforth, much will depend on realigning the range of competencies of social science as well as social scientists by contributing actively to the development of social innovation. Against this background participatory approaches that promote involvement and empowerment of civil-society actors are indispensable.

\section{INTRODUCTION}

The importance of social innovation in successfully addressing social, economic, political and environmental challenges of the 21st century is recognised not only within the Europe 2020 strategy, but also on a global scale. As a novel approach to address complex problems in global health, social care, education, energy, and environmental policies, social innovation has been embraced by stakeholders and communities on the local, regional and even national level (Franz et al. 2012; Hochgerner 2013. Moulaert et al. 2013; Nicholls et al. 2015).

The term "Social Innovation" can be traced back to the early 19th century, long before technological-economic connotations determined the common understanding of innovation (Godin 2012, pp. 21). Nevertheless, there is no shared understanding of social innovation in the sense of a clear differentiation from other concepts such as social entrepreneurship or business innovation based on new technologies, organisational features and marketing models. Likewise, there is no integration of social innovation in a comprehensive innovation policy (Howaldt et al. 2014).

We define social innovation as a new combination and/or new configuration of social practices in certain areas of action or social contexts, prompted by certain actors or constellations of actors in an intentional targeted manner with the goal of better satisfying or answering needs and problems than is possible on the basis of established practices. An innovation is therefore social to the extent that it, conveyed by the market or "non/without profit", is socially accepted and diffused throughout society or in certain societal sub-areas, may become transformed depending on societal circumstances (context) and ultimately institutionalised as a new social practice or made routine. As every other innovation, "new" does not require absolute or genuine novelty: Most innovations are new in relative terms, i.e. transferred or disseminated to another region, city or social grouping, other sectors and policy fields. Moreover, an innovation termed social innovation does not necessarily provide impact that is "good" for all or "socially desirable" in an extensive and normative sense. Accordingly, the actors' practical rationale, social attributions for social innovations are generally uncertain (Howaldt/Schwarz 2010).

With a focus on social practices, their reproduction and change as the central element of sociality, "Social Practice Theories" (SPT) allow for identifying the social dynamics of change processes. This modified understanding of the social as social practices opens the view on their reconfiguration as a core element of social innovation and social change (Shove et al. 2012). The social world is therefore composed of very spe- 
cifically nameable, individual, although interdependent practices of governance and organising; partnership; negotiations; self (cf. Reckwitz 2003); comfort, cleanliness and convenience (Shove 2003); working and nurturing (Hargreaves et al. 2013), and; consumption (Brand 2010).

Therefore it does not surprise that in the context of the broad social debate surrounding sustainable development and necessary social transformation processes (Loorbach/Rotmans 2010), the question of the relationship between social innovations and social change becomes important (Avelino et al. 2014): How can processes of social change be initiated which go beyond the illusion of centralist management concepts to link social innovations from the mainstream of society to the intended social transformation processes (McGowan/Westley 2015)?

But what are the conditions under which social innovations flourish and create impact? Who are the stakeholders? How do social innovations diffuse and lead to social change? Against this background, a new generation of EU-funded projects worked on a sound theoretical understanding of social innovation and its relation to (transformative) social change to contribute to a better understanding of the conditions under which social innovations develop, flourish and finally increase their societal impact (chapter 2).

This also raises the question of the role of universities in general and of social sciences in particular in social innovation processes. It will be a major challenge for the development of social innovation to ensure a much higher involvement of research and education facilities (chapter 3). In these processes social sciences will be challenged to redefine their functions with regard to innovation. Against that background participatory approaches that promote participation and empowerment of civilsociety actors are indispensable to increase impact (Howaldt/Schwarz 2010) (chapter 4).

\section{THE GROWING IMPORTANCE OF SOCIAL INNOVATION - "A GLOBAL MAPPING OF SOCIAL INNOVATION INITIATIVES"}

Recent years have witnessed the emergence of this new type of innovation, as an object of research and development appearing in a variety of forms and influencing our lives. There is a growing consensus among practitioners, policy makers and the research community that technological innovations alone are not capable of overcoming the social and economic challenges modern societies are facing. This is why a vast number of social innovation initiatives in different world regions providing new levers for solving problems and contributing to social change, can be identified.

The first global mapping of social innovation initiatives, which was conducted in the SI-DRIVE (Social Innovation: Driving Force of Social Change) project, revealed the importance of social innovation in addressing social, economic, political and environmental challenges of the 21st century on a global scale. It demonstrates the need for social innovation to overcome the (policy field related) societal challenges and social demands. In many policy fields we find a variety of social innovation initiatives (see figure 1).

Social innovations change the manner in which we live together (shared housing), work (telework), consume (car-sharing), distribute wealth (unconditional basic income) or deal with economic crises (short time work instead of termination). Social innovations provide new forms of collaboration between people (co-working spaces), organisations (private-public-partnerships) and states (agreement on the free movement of labour). Social innovations can emerge within different sectors: in civil society (urban farming), politics (parental leave), and economy

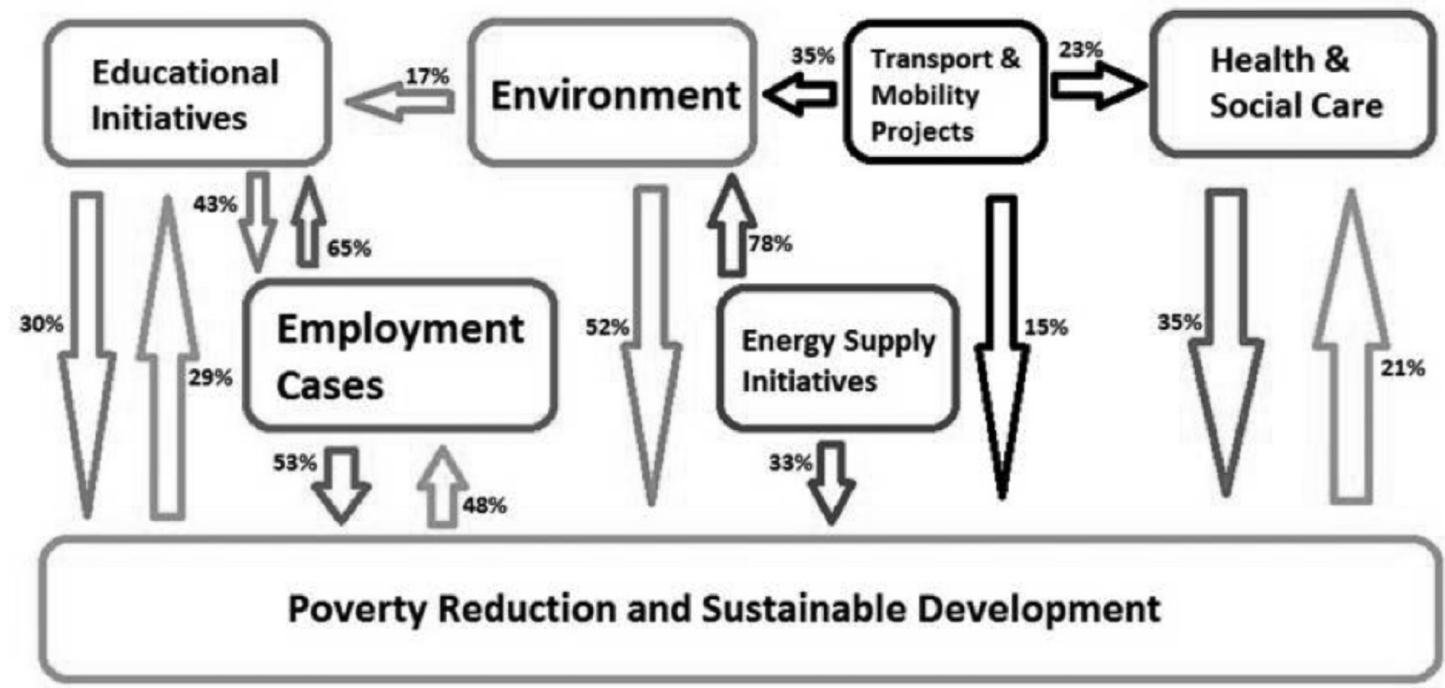

Figure 1. Social innovations cross policy fields. 
(micro credits). In short: social innovations in a sense of new practices are omnipresent and contribute to social change. The establishment of new social practices does play a prominent role in making mobility more environmentally friendly, diseases less scary or the energy turn around more successful. The high diversity of social needs and societal challenges addressed by the initiatives are not limited to one but often work across several policy fields. Social innovation has become a ubiquitous concept (Howaldt et al. 2016).

At the same time the global mapping demonstrated the capacities of social innovations to modify or even re-direct social change and to empower people -i.e. to address a wide variety of stakeholder groups, as well as the broader public, in order to improve social cohesion and to allow for smart, sustainable and inclusive growth (Howaldt et al. 2018). The mapping empirically shows that the societal and governance systems in which the social innovations are embedded are complex, the problems addressed are deeply rooted in established practices and institutions and that many initiatives are small in scale. Therefore, to better understand this relationship between social innovation and social change, the social embeddedness of any innovation in a dense network of existing practices, routines, institutions and context conditions, on the one hand, and innovation streams, on the other hand, has to be analysed. Any social innovation results in an outcome for those involved, yet to disseminate an impact further into society depends on specific conditions and mutual resonance between various social innovations. Growing social numbers and the range of social innovations may be likely to affect pace and perhaps directions of social change. Thus, social innovation in general has an impact on societal development, just as innovations in business are meant to have an impact on economic development and growth. The impact of social innovations varies (in every case) from raising awareness, which is essential in the ideation phase and the starting point of initiatives to create and implement an innovation, up to the formation of institutions (which is not necessarily the same as institutionalisation of new innovative practices, but often required to ensure the sustainability of social innovation). The mapping shed light on the great many, often nameless but still important, social innovations responding to specific and every-day social demands or incremental innovations (Howaldt et al. 2016).

Social innovative projects and initiatives aim to address social needs and societal challenges rather than focusing primarily on economic success and profit. Referring to a distinction introduced by BEPA ("Bureau of European Policy Advisers") who suggests that "the output dimension refers to the kind of value or output that social innovation is expected to deliver: a value that is less concerned with mere profit, and including multiple dimensions of output measurement" $(2010$, p. 26) there are three societal levels on which output may take place. In this understanding, social innovations

- "respond to social demands that are traditionally not addressed by the market or existing institutions and are directed towards vulnerable groups in society [...],

- tackle 'societal challenges' through new forms of relations between social actors, [...] respond to those societal challenges in which the boundary between social and economic blurs, and are directed towards society as a whole [...],

- or contribute to the reform of society in the direction of a more participative arena where empowerment and learning are both sources and outcomes of well-being" (ibid., p. 29).

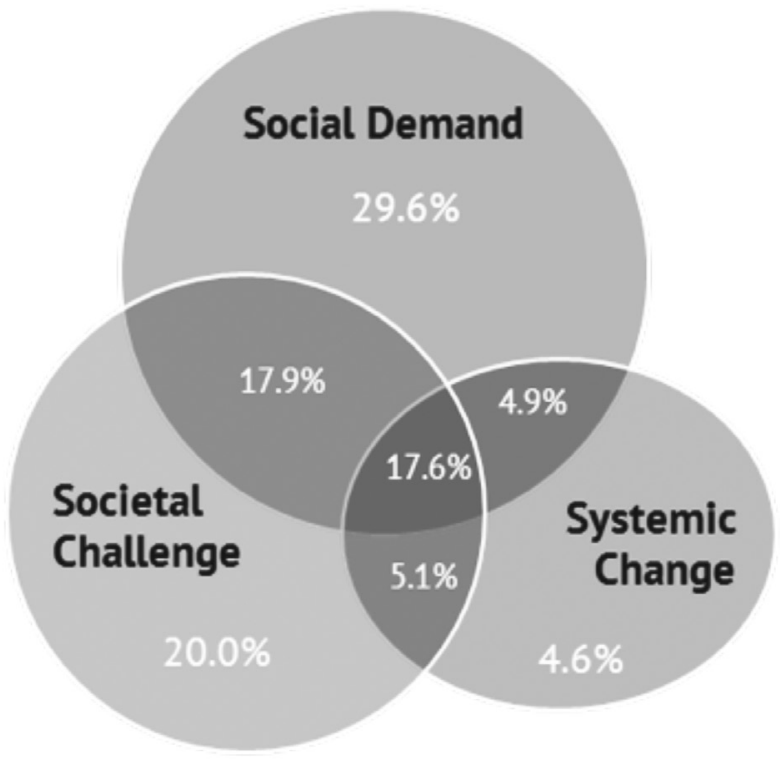

Figure 2. Societal level the initiative is addressing.

As figure 2 illustrates, most initiatives do not address one societal level alone, but rather different combinations. At the same time, the societal level addressed by the initiatives is varying in the different policy fields with a strong focus on social needs in most of the policy fields, except for "Transport and Mobility" and "Energy Supply", which both have a stronger orientation towards societal challenges. This result is also reflected in the feedback from policy workshops which highlights the dominant practice fields: cooperatives and wellconnected neighbourhood initiatives in the field of "Energy Supply" are mostly working on an agenda which goes beyond concrete and local social demands, and so do mobility clusters of inclusiveness/access dimension and greening mobility in the field of "Transport and Mobility". Global developments such as oil prices, environmental change and standard of living are considered a central driver in both policy fields.

At the same time, the global mapping revealed the diversity of the challenges modern societies are facing and the complexity of innovation processes. The mapping demonstrated that, like technological innovations, successful social innovations are based on numerous presuppositions and require appropriate infrastructures and resources. Moreover, social innovations require specific conditions because they aim at activating, fostering, and utilising the innovation potential of the whole society (BEPA 2010). Therefore, new ways of developing and diffusing social innovations are necessary (e.g. design thinking, innovation labs etc.) as well as additional far reaching resources, in order to unlock the potential of social innovation in society and to enable participation of the relevant actors and civil society.

This is not only a matter of appropriate funding but also of new participation and collaboration structures, co-creation and user involvement, empowerment and human resources development (see figure 3). Attention has to be paid to the invention and its development as well as its diffusion and imitation. From this innovation process and development perspective, resources, capabilities and constraints, drivers and barriers are not only relevant for the invention and implementation, but also for scaling and diffusion of successful innovations. 


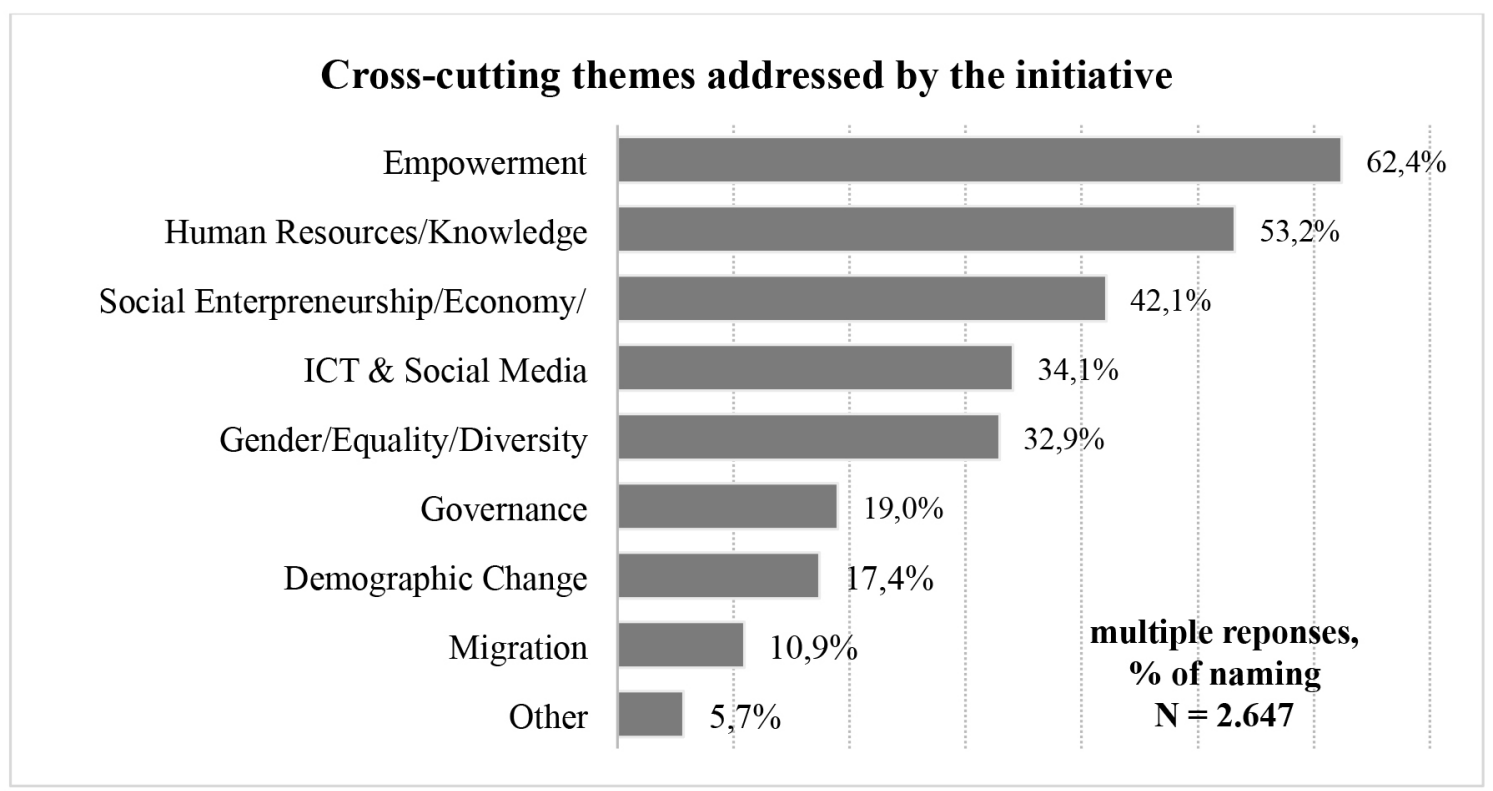

Figure 3. Cross-cutting themes addressed by the initiative.

To overcome societal challenges, cross-sector collaboration is crucial, actively involving public, economic and civil society partners - including active user or beneficiary involvement in almost half of the social innovation initiatives. This shows that most of the initiatives develop new alliances, guarantee cross-sector fertilisation and mobilise civil society (also proved by the high number of volunteers supporting the initiatives).

Such collaborations are picked up by at least two different heuristic models, the quadruple helix (Wallin 2010) on the one hand, where government, industry, academia and civil society work together to cocreate the future and drive specific structural changes, and the social innovation ecosystem (Sgaragli 2014) on the other hand (see figure 4), which also asks for interactions between the helix actors, adds the notion of systemic complexity and looks at both the serendipity and absorptive capacity of a system as a whole. Academic knowledge on social innovation ecosystems is very scarce and the concept is still fuzzy.

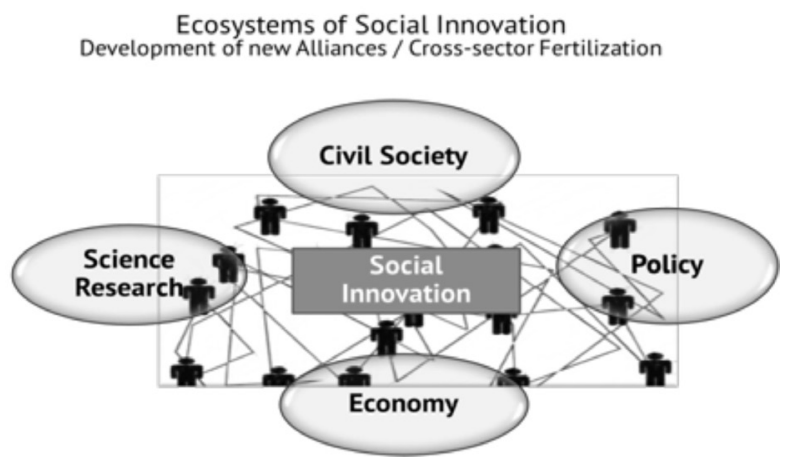

Figure 4. Social innovation ecosystem.

The results of the global mapping of the SI-DRIVE project demonstrated that social innovation processes and the underlying resources, capabilities and constraints are related to the actors of the different sectors of the social innovation ecosystem. This includes a new role of public policy and government for creating suitable framework and support structures, the integration of resources of the economy and civil society as well as supporting measures by science and universities (e.g. education for social innovation performance, know-how transfer).

While private companies, public bodies and Non-Governmental Organisations/Non-Profit-Organisations NGOs/NPOs are involved in the majority of initiatives, surprisingly, social enterprises are engaged only in minor parts of the initiatives. Additionally, academia is only a partner in some of the social innovation initiatives (see figure 5).

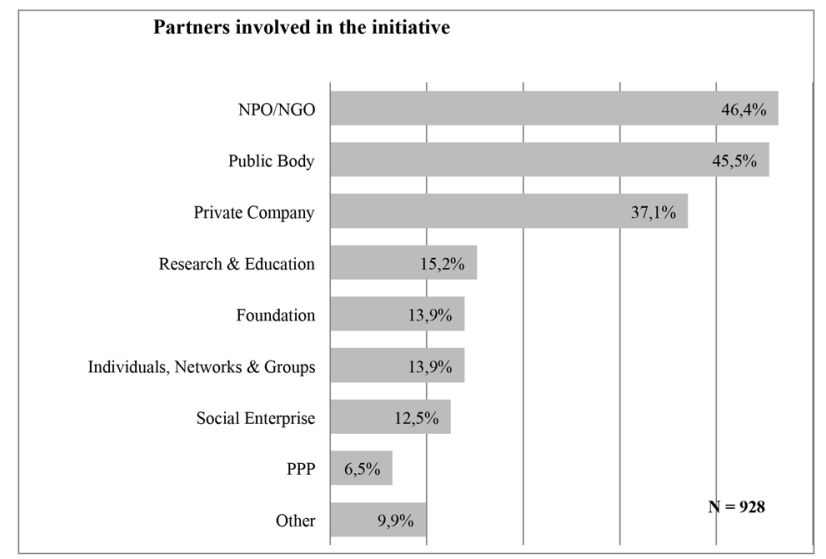

Figure 5. Partners involved in the initiative.

The marginal engagement of research and education facilities is in strong contrast to their essential role as knowledge providers in classical innovation processes (Mowery/Sampay 2005) and as one actor of the triple helix model. 
3. THE MISSING LINK THE ROLE OF "HIGHER EDUCATION INSTITUTES" (HEIS) IN SI-PROCESSES

This raises the question of the role of universities in general and of social sciences in particular in social innovation processes (see chapter 4). The marginal engagement of research and education facilities shown in the mapping, is in strong contrast to their essential role as knowledge providers in classical innovation processes and as one actor of the triple helix model. That means that at this time we find an uncompleted ecosystem of social innovation (quadruple helix) with one important pillar missing. It will be a major challenge for the development of social innovation to ensure a much higher involvement of research and education facilities.

The shift in focus towards social innovation means more than just taking new or other phenomena into account. To the extent that something new occurs at the level of social practices and not in the medium of technical artefact, a fundamental conceptual realignment in innovation research is necessary. It relates "to living together in communities and society" and concretely means "new forms of participation and social integration, of reconciling interest and social justice as well as individuality and solidarity" (Rammert 2010, p. 43).

Against that background the role that HEls are playing in social innovation has evolved in recent years. Besides researching transformation processes, more approaches in which science itself is considered as an active participant in processes of social innovation are increasingly coming to the fore. Concepts such as "Design Thinking" or "Transformative Research" with focus on active participation of stakeholders are becoming more important for the work of HEls with their environments (Schneidewind/Singer-Brodowski 2013). Through transformative research, science seeks to solve societal problems by activating processes of societal change. Against this background, the creation of appropriate structures ("Living Labs" and other spaces for exploration and learning) that help to develop knowledge based on experience in order to establish new social practices has received growing attention and needs to be further promoted. Only by sensitising people about societal problems and possible solutions, HEls can advance the development of social innovation with community members. Through concepts, such as "Service Learning" or "Explorative Learning", knowledge and experience of students are taken on and links between academia and society are developed, with the latter becoming an important partner in addition to economy. This also includes the question of new modes of knowledge production and scientific co-creation of knowledge aiming at an integration of practitioners and social innovators in the innovation processes (Nowotny et al. 2001).

Nevertheless, there are several challenges that HEls need to meet in order to advance in the area of social innovation. First, they need to understand better what social innovation is: while more and more HEls recognise the importance of social innovation for societal development and the need to engage in this area, they do not necessarily understand what social innovation is exactly about (e.g., it is often confused with the area of "University's Social Responsibility", which does not necessarily refer to (social) innovations). Hence, as long as those who work in this area and aim at introducing change have no clear concept and understanding of social innovation, it will be difficult to succeed.

This leads me to a second challenge. The topic of social innovation should be integrated along the three missions. On the one hand, social innovation is appearing on a growing number of universities' agendas, sometimes even becoming an important part of their development strategies. Some universities offer classes and degrees, such as Master or Bachelor. Others focus on research in social innovation. Probably the most common way for universities to engage in this topic that we can observe is related to manifold activities within what is usually referred to as the third mission (here mainly understood as social responsibility, outreach and engagement). On the other hand, we can rarely see a university where social innovation is major part of the strategy and integrated in all three missions (McKelvey/Zaring 2017). Therefore, the challenge is not only to develop activities in teaching, research and the third mission. It is the issue of integrating social innovation along the three missions in a comprehensive way: the work in every "mission" needs to be connected to the work in other missions, so that it can benefit from the others.

Third, there are two interrelated, fundamental characteristics of university support for social innovation that need to change: i) social innovation support activities tend to be ad hoc and largely altruistic, ii) as a result, while commercial innovation is recognised and institutionally supported by well-established knowledge transfer offices, there is no professional support function within universities for supporting social innovation. Until now, neither the infrastructure nor the funding has existed to make this possible, largely because governments and even university executives have been resistant to the notion of social innovation as an effective socioeconomic instrument. The adoption of social innovation at a policy level by governments throughout the world is creating an environment in which institutional support for this area becomes increasingly prevalent with funders willing to invest in projects.

Fourth, there is a challenge of integrating both the top-down and the bottom-up perspective. Usually, when universities assume their role as socially responsible institutions regarding their environment, they start developing initiatives, which are supposed to favour different target groups (e.g. communities). However, such initiatives tend to be designed and implemented from the university's perspective, missing to involve the target group right from the start. It is not surprising then that projects developed by HEls do not necessarily respond to the needs, the ideas and the visions of communities and other target groups. HEls have to learn how to work with target groups on equal footing and how to integrate their own perspective with the latter's perspective (Anderson et al. 2018).

\section{PARTICIPATORY APPROACHES IN SOCIAL INNOVATION RESEARCH}

While the future engagement of HEls in social innovation is crucial with regard to the impact of social innovation for societies, particular attention should be paid to the role of social sciences. It will be necessary to overcome the traditional "division of labour" in innovation processes between natural and engineering sciences, on the one hand, and social 
sciences and the humanities, on the other hand: "Natural and engineering sciences are different from social sciences and the arts primarily in that the former produce innovations or the prerequisites for innovations while the latter reflects on the emergence, the implementation and the success of innovation or also seek to explain the process" (Blättl-Mink 2006, p. 31). In the past, innovation research in the context of social sciences has helped to explain the social dimensions, the complexity and paradoxes of innovation processes.

Specifically in its analytical function, research in the social sciences contributed greatly to conceptually processing the social prerequisites for innovation and the social character of innovation processes. Its strengths rest in the analysis of innovation processes and their contextual circumstances. The findings picked up here have permeated social consciousness deeply, have determined the thinking and action of social actors and have contributed significantly to establishing a new sociologically enlightened innovation paradigm.

Shifting the perspective on innovation from technical to social innovation as an independent type of innovation, the present self-limitation of the social sciences to the concomitant research associated with a reference to the complexity and paradoxically loaded nature of innovation proves to be insufficient. For it is here that the subject matter of innovation itself rests immediately in the disciplinary perspective and the affiliated capacity for action and formation.

In the classical process of social science production, research takes place in research institutions society being an excursion for mining, an empirical source of data and information but not a partner, in the best case, also the address of transfer activities once research is concluded. But social science production can be seen as a social production of science. Social actors from the fields of social action relevant to the research theme or project participate in the whole process of research. Social scientists are social actors among others with the special task and role of driving the process towards the production of knowledge, knowledge achieving varying scopes of relevance: from "simple" problem solving with and for individual partners to general problem solutions in processes of societal transformation. Practitioners from civil society, companies and institutions - all these groups work together creating new knowledge. So the different forms of knowledge created have to be combined and tested to evolve into socially robust knowledge (Nowotny et al. 2001).

Purely analytical concepts fall short precisely in relation to the specific content of social innovations. After all, as mentioned previously, social innovations (in contrast to technological innovations) are a natural subject of the social sciences in terms of content, and as such social innovation can be not only analysed and indicated from a level of comprehension, but also be engendered and (co)shaped in terms of its (social and societal) preconditions, repercussions, etc.. Thus, it is hardly surprising that the role of the social sciences in examining and shaping social innovation is an important issue in the international scientific discussion on social innovation with a strong focus on participatory approaches that promote participation and empowerment of civil-society actors (Howaldt/ Schwarz 2010)'.

\subsection{THE CONCEPT OF WOLFGANG ZAPF}

Already Wolfgang Zapf connected the analysis of the meaning and specifics of social innovations with the question about the role and possibilities of the social sciences in researching social innovations (ZAPF 1989, p. 182 et seq.). Zapf emphasises that it is precisely the applicationoriented "tools for making decisions [delivered by the social sciences] forecasts, incremental planning, social experiments, evaluation, practices for mobilisation and motivation - (...) that [can] indeed enhance the ability of modern societies to solve problems and direct themselves" (ibid., p. 183). Zapf distinguishes potential contributions the social sciences can make to social innovation:

- decision-making support (survey research, personality tests, risk assessment and technology impact, human resources planning, etc.),

- sources of social technologies (quality management, co-determination model, group therapy),

- approaches to general theory in order to better understand innovation and productivity (1989.);

This sort of understanding of innovation processes requires developing appropriate forms of co-operation between science and practice that are not centrally focused on the transfer of expert knowledge into social practice. The aim of the conception of co-operation is to organise the process of change itself as a learning process that fosters the development and skills of every actor involved and enhances their ability to determine and reflect.

\subsection{SOCIAL INNOVATION IN LOCAL AND REGIONAL DEVELOPMENT}

One of the most prominent areas in which the concept of social innovation has increasingly become a research focus in the social sciences is local and regional development. It is the urban context in which challenges such as the effects of the economic crisis, demographic or climate change become directly visible as pressing social demands. And it is the cities where unlikely collaborations emerge to tackle problems when new competences are handed down from national or regional levels without corresponding budget allocations (Moulaert et al. 2013).

In Europe, a series of research projects delivered important findings on the role of the local level for social innovation; the latter mainly viewed under the perspective of the social economy. For example, the project "Integrated Area Development" (IAD) dealt with challenges faced by neighbourhoods and provided "an alternative to the more prevalent forms of market-led economic development" (Moulaert et al. 2013b, p. 19). Another important project in order to better understand the role of social innovation in community building was SINGOCOM (Social Innovation, Governance and Community Building). Findings from SINGOCOM also essentially contributed to the understanding of governance processes on the local level. For example, by focusing on the governance structures of neighbourhood management, it was possible to describe and analyse

1 Social innovation research can thereby build up on the long tradition of participatory approaches in social sciences (e.g. action research etc.) (Gustavsen 2012) 
how a direct link between the needs and demands of excluded groups and the resources to tackle them can be established (Moulaert et al. 2005). It showed that social innovations involve different dimensions such as the relation to culture, social connection and identity - going beyond material and economic issues (Moulaert et al. 2013b, p. 9).

The "International Handbook on Social Innovation", published by a group led by Frank Moulaert, presents a research perspective on social innovation that has been developed cooperatively over the last thirty years and which is intended to be a coherent methodological perspective that deals both conceptually and practically with structural, political and cultural forces that generate social exclusion. Furthermore, it has the potential for social change and socially innovative initiatives, and combines societal well-being with the shaping and organisation of society (Moulaert et al. 2013). The approach centres on a three-dimensional frame of reference that consists of the mutually associated defining characteristics of social innovation: satisfying needs in the sense of human development, reconfiguration of social relationships, and empowerment or political mobilisation. At the same time, the aim is to develop and demonstrate a specific type of social innovation research that seeks to find the right balance between "research on action", "action in research" and "research through and by action" (Moulaert et al. 2013a, p. 6), and that illustrates the extraordinary importance of social innovation as a field both of research and of action and social change (cf. ibid., p. 5).

According to the authors, social innovation is about a completely new ontology, which has to do with socialised change practices instead of organisational efficiency and an optimised use of knowledge. This notion of a different ontological perspective and an orientation towards a constitutive, performative role of social practices and their transformative potential is an interesting idea which would be worth further development.

In this sense, social innovation is an arena for a deliberating kind of decision-making with a transformative power, based on political negotiation at local/regional level by publics created by the political power of social movements. In this arena, social innovation researchers can be active actors: Social innovation research becomes an interactive process of research and action, starting from a collective discussion and decision by a transdisciplinary group regarding the problems of human development that should be addressed and which questions explored, what the composition of the team should be, and what the meta-theoretical frame of reference should look like.

\subsection{EMPOWERMENT AND DESIGN-THINKING}

The BEPA report supports this view when emphasising that social innovations have the function of mobilising citizens to take an active part in innovation processes and thereby enhance society's generic innovative capacity (BEPA 2010). Here, new models of governance in favour of self-organisation and political participation are required, allowing unexpected results through the involvement of stakeholders. ${ }^{2}$ If social innovation also has to do with innovation in social relations (Moulaert et al. 2013b), then it can be expected to become what former EC-President Barroso referred to as part of a new culture of empowerment (Franz et al. 2012). This notion of culture becomes important when the conditions for social innovations are not restricted to the level of actors, but understood as an ecosystem, a "complex environment in which social innovations are created, develop and flourish, on the one hand, and take effect or perish, on the other hand" (Eckhardt et al. 2017, p. 73).

Against this background different concepts of design thinking and related approaches have gained attention over the past years in a wide range of contexts beyond the communities of designers and design researchers including the discussion of social innovation. "The core idea is that the ways professional designers solve problems is useful in different contexts where individuals and groups in economy and society try to innovate and make change happen. This section reviews the core ideas of the concept of design thinking with regard to social innovation and social change" (Schaper Rinkel/Wagner-Luptacik 2014, p. 97).

In the Critical Literature Report of the SI-DRIVE project the role of design thinking in innovation processes summarised:

"Design thinking has become a dominant issue in contemporary design discourse and rhetoric, especially with the design thinking practice of the design and innovation firm IDEO, and with the application of its concept to design education at prestigious d.school, the Institute of Design at Stanford University (Bjogvinsson et al., 2012). The main characteristic of design thinking is its approach to think beyond the omnipotent designer and to overcome the obsession with artefacts, products, and things (Bjogvinsson et al., 2012). This is one of the interfaces between design thinking and social innovation approaches. Design thinking as part of design studies includes the complex social context of design to highlight the contradiction between uniqueness of design and designer as basis of business models in traditional design and the concept of transferable solutions as in social innovation concepts.

From this perspective, design thinking is closely connected with traditions such as "participatory design", "design for change" (Bjogvinsson et al., 2012, p. 101) and socially responsible design (Melles et al., 2011)". (Schaper Rinkel/Wagner-Luptacik 2014, p. 97)

As Deserti and others demonstrated, different approaches of design thinking have been developed to promote processes of social innovation by involving stakeholders in different contexts (Deserti et al. 2018, pp. 66 et seq.).

\subsection{TRANSITION RESEARCH AND DESIGN}

Social innovation research that addresses system transformation or embraces a transition perspective lays a strong focus on the reorganisation of society via participation, empowerment and social learning (cf.

2 Klein, Fontan, Harrisson, and Lévesque (2013) describe the development of the Québec Model as social innovation linked to social transformation. "From this standpoint, participative governance, co-production of services or activities, co-construction of public policies, as well as the plural character of the economy [...] represent important dimensions of social innovation" (Klein, Fontan, Harrisson, and Lévesque, 2013, p. 382). Thereby they identify the "economic turn" - "the fact that social movements have switched from merely demanding actions from other to proactive actions at the economic level" (Klein et al., 2013, p. 382) - as an important source for social innovation (Klein et al., 2013, p. 371). 
BEPA 2010; Elsen/Lorenz 2014). A whole series of more or less theoretically informed approaches that conceptually and programmatically focus on the shaping or shapeability of transformation processes in terms of sustainable and human development has been developed. Transformative social change here is not understood to be a largely uncontrolled outcome of gradual evolutionary developments (cf. Osterhammel 2011), but rather as something which can in principle be shaped by society, i.e. "by the actors and their innovations" (Schneidewind 2013, p. 123). Thus heterogeneous, more or less theoretically informed approaches (to shaping) change come to the fore, which elevate investigating and shaping the transformation process itself as well as the increasing importance of social innovations in this connection to the status of the actually relevant theme.

However, the "varied use of the term 'transformation'" (Aderhold et al. 2015, p. 135) - as can be seen in approaches such as transition management, transition design, transformation design, social design, and the Great Transformation - leads "to a conceptual uncertainty" (ibid., p. 135) rather than to a theoretically grounded, practicable model of transfor- mation (cf. Howaldt/Schwarz 2016, p.43 et seq.). Given the importance of social innovation in these discourses, as mentioned earlier, our view is that the lack of a well-developed and workable concept of social innovation that goes beyond a metaphorical description of certain phenomena and initiatives is one of the main reasons for this unsatisfactory situation ${ }^{3}$.

One transition approach which with a view to sustainable development directly aims at transforming social practices and at the same time explicitly aims to include and develop theories of change in order to better understand the dynamics of change in the social and natural world, is transition design (cf. Hopkins 2008). It aims to mobilise existing change potential in a collaborative process, and emphasises transdisciplinary and reintegration as well as the recontextualisation of knowledge. It is less about having a shaping influence on social phenomena, and more about a deeper understanding of specific environments ("ecosystems"), about the relations between its different parts, what the specific needs are, what works and what does not, and how things could develop in the future (see figure 6).

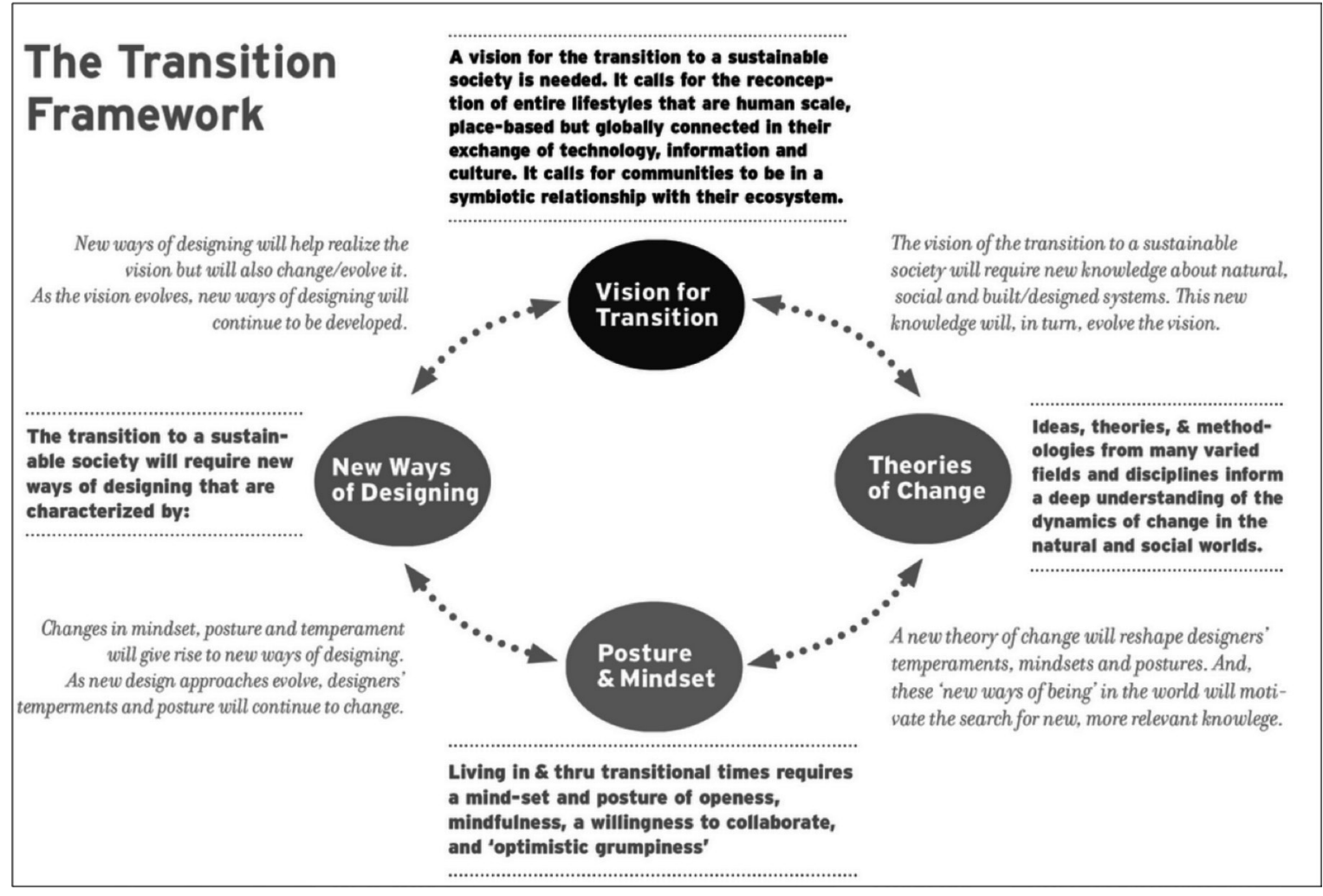

Figure 6. "The Transition Framework" (Irwin et al. 2015, p. 7).

The lack of a social-theory foundation for transformation discourse is also illustrated by the fact that, with regard to social transformation processes, recourse is often made to the multi-level perspective (MLP) (cf. Geels 2006; Geels/Schott 2007) that was developed in socio-technical innovation research, and the governance model of transition management that builds on it (cf. Loorbach 2007). In this perspective, system innovations in social functional areas such as transportation, the energy supply, food, housing, and communication are considered (cf. Geels 2005). These functional areas are characterised by specific socio-technical systems. System innovations emerge from interlinked developments on different levels. Different societal sectors, actors, practices, (learning) processes, routines, abilities, and rules play a role here, but this is always with regard to the question of their influence on the emergence, development and establishment of new technologies, and socio-technical systems or regimes that are shaped as a result.

Despite various criticisms, the approach seems to have lost little of its attractiveness as a theoretical model of the shaping of social transformation processes However, from the point of view of an understanding of social innovation that is grounded in practice theory, it does not offer any suitable basis for an appropriate understanding of social transformation processes. It systematically ignores the change dynamics of social practices and is therefore unable to capture the importance of social innovations in transformation processes (cf. Avelino et al. 2014). 
One prominent application of transition design is the transition town movement (http://www.transition-initiativen.de) initiated by Rob Hopkins, and the embedded transition research network (http://www.transitionresearchnetwork.org), which aims to bring together and promote transition initiatives and transition research. Around the world, some 500 transition initiatives are now registered, and have initiated diverse social innovations at local level (https://www.transitionnetwork.org).

The transition town movement can be interpreted as a concretisation of the post-growth economy and economy for the common good (cf. Pufe 2014, p. 276). Here it is not a question of theories, but of practice which itself "is the intellectual equipment for the process of transforming society as a whole, for an economy and a society that is on its way into and through the 21st century" (ibid., p. 291).

In the German sustainability discussion, the concept of "transformation design" has gained importance in recent years. Transformation design begins with small transformation examples that affect only a limited number of people as exercises in path-changing and inspiration for similar path changes, and is here understood as shaping a necessary process of transformation of the capitalist growth economy, i.e. a change process includes changing social structures together with the corresponding power and control structures (Sommer/Welzer 2014).

\section{CONCLUSION - RETHINKING SOCIAL SCIENCE}

In the increasing discussion on social innovation new participatory concepts for social science research have been developed. While there are a lot of differences with regard to the field of action, their objectives and the addressed problems these approaches are based on the idea of developing research and innovation process with and for society.

In these briefly outlined approaches social sciences are challenged to redefine their functions with regard to innovation and societal transformation. This goes far beyond a better understanding of science or new concepts of transfer, but deeply affects the traditional academic ways of knowledge production. New modes of the production of social science and the social production of science will become necessary. "Mode 2" has been the label tagged to this newly emerging type of knowledge production by Nowotny et al. (2001) mostly referring to natural or engineerial sciences.

There is a large gap between the traditional understanding of social research and science and the new mode of generating socially robust knowledge under the framework conditions as we have outlined them. The new mode of knowledge production will definitely require a thorough review of the classical quality criteria of what is scientific along with the development of new concepts, methods, procedures and organisational structures. The discussion about such an innovative approach to the production of social science as a process of social production could be very valuable for understanding the specific contribution of the social sciences to processes of innovation and societal transformation 4 .

In the past, innovation research in the context of social sciences has contributed to explain the social dimensions, the complexity and paradoxes of innovation processes. Henceforth, much will depend on realigning the range of competencies of social science as well as social scientists by contributing actively to the development and integration of innovations as well as by developing social innovation. The great challenge for contemporary innovation research lies in analysing its potential in the search for new social practices that enable us to secure the future and allow people to live "a richer and more fulfilled human life" (Rorty 2008, p. 191).

Against that background participatory approaches that promote participation and empowerment of civil-society actors are indispensable. The requisite know-how is found not only in the sociology of technology, economic sociology, and organisational sociology (cf. Blättel-Mink 2006) but also in the debate about the importance of stakeholder involvement to increase the impact of the social sciences and humanities (Spaapen/ van Drooge 2011). This also includes the question of new modes of knowledge production and scientific co-creation of knowledge (Nowotny et al. 2001) aiming at an integration of practitioners and social innovators in the innovation processes (Soler Gallart 2017). There is a lot of evidence that social innovation research will become of growing importance not only with regard to social integration and equal opportunities but also with regard to preserving and expanding the innovative capacity of society as a whole.

\section{REFERENCES}

Aderhold, J., Mann, C., Rückert-John, J. and Schäfer, M. (2015). Experimentierraum Stadt: Good Governance für soziale Innovationen auf dem Weg zur Nachhaltigkeitstransformation. Umweltforschungsplan des Bundesministeriums für Umwelt, Naturschutz, Bau und Reaktorsicherheit, TEXTE 04/2015. Retrieved April 8, 2018 from: https://www. umweltbundesamt.de/sites/default/files/medien/378/publikationen/ texte_04_2015_experimentierraum_stadt_good_governance.pdf.

Anderson, M. M., Domanski D. and Howaldt, J. (2018). Social Innovation as a chance and a challenge for Higher Education Institutions. In J. Howaldt, C. Kaletka, A. Schröder and M. Zirngiebl (Ed.), Atlas of Social Innovation. New Practices for a Better Future (pp. 50-53). Dortmund: Sozialforschungsstelle, TU Dortmund University.

Avelino, F., Wittmayer, J., Haxeltine, A., Kemp, R., O'Riordan, T., Weaver, P., Loorbach, D. and Rotmans, J. (2014). Game-changers and Transformative Social Innovation. The Case of the Economic Crisis and the New Economy. TRANS/T working paper. Retrieved April 8, 2018 from: http://www.transitsocialinnovation.eu/content/original/TRANSIT\%20 outputs/91\%20Gamechangers_TSI_Avelino_etal_TRANSIT_workingpaper_2014.pdf.

BEPA (Bureau of European Policy Advisers) (Ed.) (2010). Empowering People, Driving Change. Social Innovation in the European Union. Luxembourg: Publications Office of the European Union. Retrieved April 8, 2018 from: http://www.transitsocialinnovation.eu/resource-hub/empoweringpeople-driving-change-social-innovation-in-the-european-union.

Bjogvinsson, E., Ehn, P. and Hillgren, P.-A. (2012). Design Things and 
Design Thinking: Contemporary Participatory Design Challenges. Design Issues, 28(3), 101-116.

Blättel-Mink, B. (2006). Kompendium der Innovationsforschung. Wiesbaden: VS Verlag für Sozialwissenschaften.

Brand, K.-W. (2010). Social Practices and Sustainable Consumption: Benefits and Limitations of a New Theoretical Approach. In M. Gross and H. Heinrichs (Ed.), Environmental Sociology: European Perspectives and Interdisciplinary Challenges (pp. 217-235). Dordrecht: Springer.

Deserti, A., Rizzo, F. and Cobanli, 0. (2018). From Social Design to Design for Social Innovation. In J. Howaldt, C. Kaletka, A. Schröder and M. Zirngiebl (Ed.), Atlas of Social Innovation. New Practices for a Better Future (pp. 65-68). Dortmund: Sozialforschungsstelle, TU Dortmund University.

Eckhardt, J., Kaletka, C. and Pelka, B. (2017). Inclusion through digital social innovations. Modelling an ecosystem of drivers and barriers. In M. Antona and C. Stephanidis (Ed.), Universal access in human - computer interaction, UAHCI 2017 Proceedings, Part / (pp. 67-84). Springer.

Elsen, S. and Lorenz, W. (2014). Social innovation, participation and the development of society: Soziale Innovation, Partizipation und die Entwicklung der Gesellschaft. Bolzano: University Press.

European Commission (2012). Responsible Research and Innovation. Europe's ability to respond to societal challenges. Retrieved August 10, 2018 from: https://ec.europa.eu/research/swafs/pdf/pub_rri/ KI0214595ENC.pdf.

Franz, H.-W., Hochgerner, J. and Howaldt, J. (2012). Challenge Social Innovation: Potentials for Business, Social Entrepreneurship, Welfare and Civil Society. Berlin, New York: Springer.

Geels, F.W. and Schot, J. (2007). Typology of sociotechnical transition pathways. Research Policy, 36 (3), pp. 399-417.

Geels, F.W. (2005). Process and patterns in transitions and system innovations: Refining the co-evolutionary multi-level perspective. Technological Forecasting and Social Change, 72(6), pp. 681-696.

Geels, F.W. (2006). Multi-level Perspective on System Innovation. In X. Olsthorn and A. J. Wieczorek (Ed.), Understanding Industrial Transformation (pp. 163-186). Dordrecht: Springer.

Giesecke, D. (2014). Postwachstum: Geschichten „zur Senkung der Arbeitsmoral". WSI Mitteilungen 7/2014, 551-554.

Godin, B. (2012). Social Innovation: Utopias of Innovation from c. 1830 to the Present. Project on the Intellectual History of Innovation. Working Paper No. 11. Montreal.

Groß, M., Hoffmann-Riem, H. and Krohn, W. (Ed.) (2005). Realexperimente. Ökologische Gestaltungsprozesse in der Wissensgesellschaft. Bielefeld: Transcript.

Gustavsen, B. (2012). Social Innovation and Action Research. In H.-W.
Franz, J. Hochgerner and J. Howaldt (Ed.), Challenge social innovation: Potentials for business, social entrepreneurship, welfare and civil society (pp. 353-366). Berlin, New York: Springer.

Hargreaves, T., Haxeltine, A., Longhurst, N. and Seyfang, G. (2013). Up, Down, Round and Round: Connecting Regimes and Practices in Innovation for Sustainability. Environment and Planning, 45 (2), 402-420.

Hochgerner, J. (2013). Social Innovation and the Advancement of the General Concept of Innovation. In C. Ruiz Viñals and C. Parra Rodríguez (Ed.), Social Innovation. New Forms of Organisation in Knowledge-based Societies (pp. 12-28). Oxon: Routledge.

Hopkins, R. (2008). The Transition Handbook: from oil dependency to local resilience. White River, VT: Chelsea Green.

Howaldt, J. and Schwarz, M. (2010). Social Innovation: Concepts, Research Fields and International Trends. IMO International Monitoring. Dortmund: Sozialforschungsstelle, TU Dortmund University. Retrieved June 12, 2018 from: http://www.sfs.tu-dortmund.de/odb/Repository/ Publication/Doc/1289/IM0_Trendstudie_Howaldt_Schwarz_englische_ Version.pdf.

Howaldt, J. and Schwarz, M. (2016). SI-DRIVE Report: Social Innovation and its Relationship to Social Change. Dortmund: Sozialforschungsstelle, TU Dortmund University. Retrieved October 24, 2018 from https://www. si-drive.eu/wp-content/uploads/2016/07/SI-DRIVE-D1-3-Social-Changefinal-260416-2.pdf.

Howaldt, J., Butzin, A., Domanski, D. and Kaletka, C. (2014). Theoretical Approaches to Social Innovation: A Critical Literature Review. Dortmund: Sozialforschungsstelle, TU Dortmund University. Retrieved March 29, 2018: http://www.si-drive.eu/wp-content/uploads/2014/11/ D1_1-Critical-Literature-Review_final.pdf.

Howaldt, J., Kaletka, C. and Schröder, A. (2018). Social Innovation on the Rise. Results of the First Global Mapping. In J. Howaldt, C. Kaletka, A. Schröder and M. Zirngiebl (Ed.), Atlas of Social Innovation. New Practices for a Better Future (pp. 12-15). Dortmund: Sozialforschungsstelle, TU Dortmund University.

Howaldt, J., Schröder, A., Kaletka, C., Rehfeld, D. and Terstriep, J. (2016). Comparative Analysis (Mapping 1) - Mapping the World of Social Innovation: A Global Comparative Analysis across Sectors and World Regions (D1.4). Dortmund: TU Dortmund University. Retrieved May 18, 2018 from: https://www.si-drive.eu/wp-content/uploads/2016/07/SIDRIVE-D1-4-Comparative-Analysis-2016-08-15-final.pdf.

Irwin, T., Kossoff, G., Tonkinwise, C. and Scupelli, P. (2015). Transition Design 2015. A new area of design research, practice and study that proposes design-led societal transition toward more sustainable futures. Pittsburgh. Retrieved 0ctober 24, 2018 from: http://design.cmu.edu/sites/default/files/Transition_Design_Monograph_final.pdf.

Klein, J. L., Fontan, J. M., Harrisson, D. and Lévesque, B. (2013). The Quebec Model: a social innovation system founded on cooperation and consensus building. In F. Moulaert, D. MacCallum, A. Mehmood, and A. Hamdouch 
(Ed.), The International Handbook on Social Innovation: Collective Action, Social Learning and Transdisciplinary Research (pp. 371-383). Cheltenham: Elgar.

König, T., Nowotny, H. and Schuch, K. (2018). Impact re-loaded. Pathways to impact from SSH research. Retrieved October 24, 2018 from: https://www.ssh-impact.eu/impact-re-loaded/.

Loorbach, D. and Rotmans, J. (2010). The Practice of Transition Management: Examples and Lessons from Four Distinct Cases. Futures, 42 (3), pp. 237-246.

Loorbach, D. (2007): Transition Management. New mode of governance for sustainable development. Utrecht: International Books.

McGowan, K. and Westley, F. (2015). At the Root of Change: The History of Social Innovation. In A. Nicholls, J. Simon and M. Gabriel (Ed.), New Frontiers in Social Innovation Research (pp. 52-68). London: Palgrave Macmillan.

McKelvey, M. and Zaring, 0. (2017). Co-delivery of social innovations: exploring the university's role in academic engagement with society. Industry and Innovation, 25, 6, pp. 594-611. Abingdon: Routledge.

Melles, G., de Vere, I. and Misic, V. (2011). Socially responsible design: Thinking beyond the triple bottom line to socially responsive and sustainable product design. Codesign-International Journal of Cocreation in Design and the Arts, 7(3-4), 143-154.

Moulaert, F., MacCallum, D., Mehmood, A. and Hamdouch, A. (2013). The International Handbook on Social Innovation. Collective Action, Social Learning and Transdisciplinary Research. Cheltenham, Northhampton: Edward Elgar.

Moulaert, F., MacCallum, D., Mehmood, A. and Hamdouch, A. (2013a). General introduction: the return of social innovation as a scientific concept and a social practice. In F. Moulaert, D. MacCallum, A. Mehmood and A. Hamdouch (Ed.), The International Handbook on Social Innovation. Collective Action, Social Learning and Transdisciplinary Research (pp. 1-6). Cheltenham, Northhampton: Edward Elgar.

Moulaert, F., MacCallum, D. and Hillier, J. (2013b). Social innovation: intuition, precept, concept, theory and practice. In F. Moulaert, D. MacCallum, A. Mehmood and A. Hamdouch (Ed.), The International Handbook on Social Innovation. Collective Action, Social Learnig and Transdisciplinary Research (pp. 13-24). Cheltenham, Northhampton: Edward Elgar.

Moulaert, F., Martinelli, F., Swyngedouw, E. and González, S. (2005). Towards Alternative Model(s) of Local Innovation. Urban Studies, 42(11), 1969-1990.

Mowery, D. C. and Sampat, B. N. (2005). Universities in National Innovation Systems. In J. Fagerberg, D. C. Mowery and R. R. Nelson (Ed.), The Oxford Handbook of Innovation (pp. 209-239). Oxford: University Press.

Nicholls, A., Simon, J. and Gabriel, M. (Ed.) (2015). New Frontiers in Social Innovation Research. London: Palgrave Macmillan.

Nowotny, H., Scott, P. and Gibbons, M. (2001). Re-thinking Science.
Knowledge and the Public in an Age of Uncertainty. Cambridge: Polity Press.

Osterhammel, J. (2011). Die Verwandlung der Welt. Eine Geschichte des 19. Jahrhunderts. München: C. H. Beck.

Pufe, I. (2014). Nachhaltigkeit. 2. Ed. Konstanz: UVK Verlagsgesellschaft $\mathrm{mbH}$.

Rammert, W. (2010). Die Innovationen der Gesellschaft. In J. Howaldt and H. Jacobsen (Ed.), Soziale Innovation. Auf dem Weg zu einem postindustriellen Innovationsparadigma (pp. 21-52). Wiesbaden: VS Verlag für Sozialwissenschaften.

Reckwitz, A. (2003). Grundelemente einer Theorie sozialer Praktiken: Eine sozialtheoretische Perspektive. Zeitschrift für Soziologie, 32 (4), 282-300.

Rorty, R. (2008). Philosophie als Kulturpolitik [Philosophy as Cultural Politics]. Frankfurt am Main: Suhrkamp.

Schaper-Rinkel, P. and Wagner-Luptacik, P. (2014). Design Thinking. In J. Howaldt, A. Butzin, D. Domanski and C. Kaletka (Ed.), Theoretical approaches to social innovation: A critical literature review (pp. 97-103). Dortmund: Sozialforschungsstelle, TU Dortmund University. Retrieved March 29, 2018 from: http://www.si-drive.eu/wp-content/uploads/2014/11/ D1_1-Critical-Literature-Review_final.pdf.

Schneidewind, U. and Singer-Brodowski, M. (2013). Transformative Wissenschaft. Klimawandel im deutschen Wissenschafts- und Hochschulsystem. Metropolis: Marburg.

Schneidewind, U. (2013). Wandel verstehen - Auf dem Weg zu einer „Transformative Literacy“. In H. Welzer and K. Wiegandt (Ed.), Wege aus der Wachstumsgesellschaft (pp. 115-140). Frankfurt am Main: Fischer Taschenbuch.

Sgaragli, F. (2014). Enabling social innovation ecosystems for communityled territorial development. Rom: Fondazione Giacomo Brodolini.

Shove, E. (2003). Comfort, Cleanliness and Convenience: The Social Organization of Normality. Oxford: Berg.

Shove, E., Pantzar, M. and Watson, M. (2012). The Dynamics of Social Practice: Everyday Life and How it Changes. Los Angeles: Sage.

Soler Gallart, M. (2017). Achieving Social Impact. Sociology in the Public Sphere. Cham: Springer.

Sommer, B. and Welzer, H. (2014). Transformationsdesign. Wege in eine zukunftsfähige Moderne. München: oekom verlag.

Spaapen, J. and van Drooge, L. (2011). Introducing 'Productive Interactions' in Social Impact Assessment. Research Evaluation, 20 (3), 211-218.

Tarde, G. (2009). Die sozialen Gesetze. Skizze einer Soziologie (1898). Marburg: Metropolis Verlag.

Von Schomberg, R. (2011). Prospects for Technology Assessment in a 
framework of responsible research and innovation. In M. Dusseldorp and R. Beevroft (Ed.), Technikfolgen abschätzen lehren: Bildungspotenziale transdisziplinärer Methoden. Wiesbaden: VS Verlag.

Wallin, S. (2010). The co-evolvement in local development - From the triple to the quadruple helix model. Paper presented at Triple Helix VIII, Madrid. Retrieved October 24, 2018 from: http://www.leydesdorff.net/th8/ TRIPLE\%2OHELIX\%20-\%20VIII\%20CONFERENCE/PROCEEDINGS/0110_ Wallin_Sirkku_0-104/triple\%20helix\%20Wallin\%20final.pdf.

Zapf, W. (1989). Über soziale Innovation. Soziale Welt, 40 (1-2), 170-183.

\section{AUTHOR}

\section{JÜRGEN HOWALDT}

Sozialforschungsstelle, TU Dortmund University, Evinger Platz 17, Dortmund, 44339 (Germany)

E: Howaldt@sfs-dortmund.de

\section{KEYWORDS:}

Social Innovation, Societal Impact, Societal Transformation, Empowerment, Participatory Approaches, Civil Society 